\title{
GHR/HindIII Locus Polymorphisms in Intron-2 GHR Gene of Papua Local Chicken
}

\author{
M. A. Mu'in* and A. G. Murwanto \\ Fakultas Peternakan, Universitas Papua, Jl. Gunung Salju, Amban, Manokwari 98314. \\ *Corresponding author: muinunipa@gmail.com
}

\begin{abstract}
This study aimed to detect single nucleotide polymorphisms (SNPs) in intron-2 on growth hormone receptor (GHR) gene in Papua local chickens using the PCR-RFLP method to study its relationship with growth characteristics. Data on the bodyweight of 49 chickens aged 1, 2, 3, and 4 months (22 males, 27 females) and DNA samples were used for this study. The DNA fragment of size $718 \mathrm{bp}$ in intron-2 of the GHR gene from the study chicken was successfully amplified using a pair of specific primers. The PCR-RFLP/HindIII analysis results found two genotypes (HindIII++ and HindIII--) in this locus. HindIII+ and HindIII- alleles were 0.02 and 0.98, respectively.
\end{abstract}

Keywords: polymorphism, GHR gene, PCR-RFLP, HindIII, Papua local chickens.

\section{INTRODUCTION}

Papuan local chickens are native chickens that have been cultivated for a long time and have adapted well in Papua. Several studies have found that the diversity of body weight and growth rate of local Papuan chickens is relatively high (Rahayu, 1990; Lumatauw et al., 1995; Mu'in, 1999; Haryani, 2000), and tends to have low body weight and slow growth. In this condition, it is necessary to strive to improve the growth of local Papuan chickens, either through improved feed, maintenance, management, or genetic improvement.

The development of molecular biology technology has now penetrated various fields, including animal husbandry. The advantages of this technology in animal husbandry include finding polymorphic loci that can be used as molecular markers for the genetic improvement of economically valuable traits. The application of molecular markers in livestock selection can accelerate genetic improvement because such a selection method (Marker-Assisted Selection, MAS) is free from environmental influences, can be applied to livestock as early as possible (young), and is not limited to certain sexes (Smith and Brascamp, 1990). Several researchers have found polymorphic loci in genes that play an important role in growth in chickens. Some of the polymorphic loci found were known to affect growth in several genetic groups of chickens (Feng et al., 1997; 1998; Stephen et al., 2001; Bingxue et al., 2003; Nie et al., 2005).

Growth hormone $(\mathrm{GH})$ is a hormone produced by acidophil cells in the adenohyphophise gland (anterior pituitary) and secreted into the blood (Lawrence and Fowler, 2002). In chicken, GH is a hormone that has a broad influence on various physiological functions, such as growth, body composition, egg production, and reproductive characteristics (Bingxue et al., 2003). Growth hormone exerts its effects on growth and another metabolism by interacting with specific receptors on cell surface targets, namely the growth hormone receptor (GHR). GHR is a cell surface receptor for $\mathrm{GH}$, and GHR must carry out its effects on target tissues (Feng et al., 1997).

In chickens, GHR is encoded by a gene located on the $\mathrm{Z}$ chromosome, measuring 4007 bps, consisting of 10 exons and nine introns. To date, 33 SNP (single nucleotide polymorphism) mutations have been found in all of these genes, consisting of 8 SNPs in the exon region, 17 SNPs in the intron region, and 8 SNPs in the $3^{\prime}$ UTR region (untranslated region) (Nie et al., 2005). Mutations in the chicken GHR gene often cause stunted growth due to decreased GH sensitivity, causing stunted chickens (Burnside et al., 1991). $\mathrm{Li}$ et al. (2008) informed that the SNP in intron-2 of the GHR gene was caused by the A/G transversion that could be detected with the HindIII enzyme.

This study aimed to detect single nucleotide polymorphisms (SNPs) in the intron-2 region of the GHR gene in Papuan local chickens using the PCR-RLP method and the HindIII restriction enzyme, as well as to test the possibility of being used as molecular markers for the growth of Papuan local chickens. 


\section{MATERIALS AND METHODS}

\section{Research methods}

The material used in this study was 49 local Papuan chickens (22 males and 27 females), originating from the hatching of local Papuan chicken eggs. The hatching eggs were obtained from several people's farms in Manokwari Regency. The hatched chickens were reared up to 4 months of age at the Experimental Farm, Faculty of Animal Husbandry, University of Papua. During maintenance, body weight was weighed every month. At the end of the rearing, a blood sample (1 $\mathrm{ml}$ per chicken) was taken from the wing vein using a vacuum tube containing $\mathrm{K}_{3}$ EDTA.

\section{Research Methods}

The implementation of this research (DNA analysis) followed the stages: (1) DNA isolation, (2) DNA quantification, (3) DNA amplification, (4) amplicon digestion, (5) genotype identification, and (6) research data analysis. DNA analysis was carried out at the Center for Biotechnology Studies, UGM, Yogyakarta. DNA isolation was carried out from blood samples using the phenol-chloroform extraction method (Sambrok et al., 1989). DNA samples were quantified/examined by spectrophotometry at OD260 and OD280 to determine the concentration and purity of the DNA samples obtained. Furthermore, through the Polymerase Chain Reaction (PCR) method, specific DNA fragments measuring 718 bp (ranging from intron-2 to partially exon-3) were amplified in the chicken GHR gene using specific primers (Feng et al., 1998), as presented in Table 1.

Table 1. Primers used for amplification of DNA fragments (718 bp) in the intron-2 region of the chicken GHR gene

\begin{tabular}{ll}
\hline Primer & Primary nucleotide sequence \\
\hline Forward (GHR-I2F) & 5'-ggc-tct-cca-tgg-gta-tta-gga -3' \\
Reverse (GHR-I2R) & 5'-gct-ggt-gaa-cca-atc-tcg-gtt-3'. \\
\hline
\end{tabular}

Source: Feng et al. (1998).

Each PCR reaction was carried out in 25 volumes, with a composition of $19 \mathrm{~L} \mathrm{ddH}_{2} \mathrm{O}, 2 \mu \mathrm{L}$ DNA solution $( \pm 50 \mathrm{ng})$, and a pair of specific primers of $2 \mathrm{~L}$ (16 pmol) each. This mixture was put into a $0.2 \mathrm{ml}$ tube of Ready-To-Go PCR Beads (Amersham Biosciences), resuspended, and then put into a PCR machine. The PCR conditions for amplifying specific DNA fragments were programmed following Feng et al. (1998), as presented in Table 2.
The PCR product obtained from the amplification results was passed under electrophoresis (100 Volt, 30 minutes) in 1.5\% agarose gel containing GoldView Nucleic Acid in $1 \mathrm{x}$ TBE. DNA markers are involved in this process. The purpose of electrophoresis of PCR products here is to ensure successful amplification. The electrophoresis results were examined under ultraviolet (UV) light and documented.

Table 2. PCR conditions for amplification of DNA fragments (718 bp) in the intron-2 region of the research chicken GHR gene

\begin{tabular}{lcc}
\hline Amplification stage & Temperature $\left({ }^{\circ} \mathrm{C}\right)$ & Time (seconds) \\
\hline 1. Initial denaturation & 94 & 300 \\
2. Amplification 35 cycles: & & \\
$>$ Denaturation & 94 & 120 \\
$>$ Annealing & 59 & 70 \\
$>$ Extension & 72 & 90 \\
3. Extra extension & 72 & 300 \\
\hline
\end{tabular}

Sumber: Feng et al. (1998).

Identification of the GHR locus genotype in the intron-2 region of the study chickens was carried out by digesting the PCR product (718 bp) of the GHR/intron-2 gene in the study chickens using the HindIII restriction enzyme. The mixture for digestion consisted of $10 \mathrm{~L}$ of PCR product, 1 
$\mathrm{L}$ of HindIII restriction enzyme, $1.5 \mathrm{~L}$ of buffer, and $2.5 \mathrm{~L}$ of ddH2O. This mixture was put into a $1.5 \mathrm{ml}$ micro-tube (Eppendorf), resuspended, and then incubated at $37{ }^{\circ} \mathrm{C}$ for 2 hours. The product was separated by electrophoresis (100 Volt, 30 $\mathrm{min}$ ) in a $1.5 \%$ agarose gel containing GoldView Nucleic Acid in $1 \mathrm{x}$ TBE. DNA markers are involved in this process. The electrophoresis results were examined under ultraviolet (UV) light and documented. The guidelines for identifying GHR loci genotypes in the intron-2 region of research chickens digested with HindIII in chickens are presented in Table 3.

Table 3. Guidelines for identifying GHR/Intron-2/HindIII loci genotypes in chickens.

\begin{tabular}{ccl}
\hline Genotype & Number of Ribbons (Fragment) & Ribbon size (bp) \\
\hline HindIII++ & 2 & 404 dan 314 \\
HindIII+- & 4 & $404,314,247$, dan 157 \\
HindIII-- & 3 & 314,247, dan 157 \\
\hline
\end{tabular}

Source: Feng et al. (1998).

Data from PCR-RFLP in the number and size of specific bands for each genotype were analyzed by calculating allele and genotype frequencies (Nei and Kumar, 2000). The formula calculated the genotype frequency (Xii) of the GHR/intron-2/HindIII locus: $\mathrm{Xii}=($ nii/N) $\mathrm{x}$ $100 \%$, while the formula calculated the allele frequency (Xi) of the GHR/intron-2/HindIII locus: $\mathrm{Xi}=(2 \mathrm{nii}+\mathrm{NIJ}) /(2 \mathrm{~N})$, where: $\mathrm{Xii}$ is the frequency of the AiAi genotype, $\mathrm{Xi}$ is the frequency of the Ai allele, NIJ is the number of $\mathrm{AiAi}$ genotypes, NIJ is the number of $\mathrm{AiAj}$ genotypes, and $\mathrm{N}$ is the number of samples.

\section{RESULT AND DISCUSSION}

\section{DNA Quantification}

Based on the results of examining the chicken DNA samples by spectrophotometry at OD260 and OD280, the average concentration of DNA samples was above $100 \mathrm{~g}(173.6 \pm 73.0 \mathrm{~g})$, and an average purity of $1.93 \pm 0.38$. The average purity level in the DNA samples was still in the normal range of 1.8 - 2.0 (Kriby, 1990; Artama,
1991; Muladno, 2002), although some DNA samples had a purity level below 1.8 and above 2.0. According to Artama (1991), low purity can be caused by contamination by protein or phenol. Kirby's (1990) recommendation: a purity level of about 1.5 purity is sufficiently pure for PCRRFLP analysis. Thus, these 49 genomic DNA samples were classified as suitable for PCR-RFLP analysis. The results of electrophoresis of DNA samples on $1.5 \%$ agarose gel are presented in Figure 1.

\section{DNA Amplification}

The success of DNA fragment amplification is influenced, among others, by the PCR conditions and the primer pair used (Kriby, 1990; Artama, 1991; Muladno, 2002). In this study, the target DNA fragment was $718 \mathrm{bp}$ in size, ranging from intron-2 to partly exon-3 of the GHR gene of the study chicken. Previous studies have shown that there is a point mutation in the target DNA fragment caused by A/G transversion and can be detected with the HindIII restriction enzyme (Feng et al., 1998; Li et al., 2008).

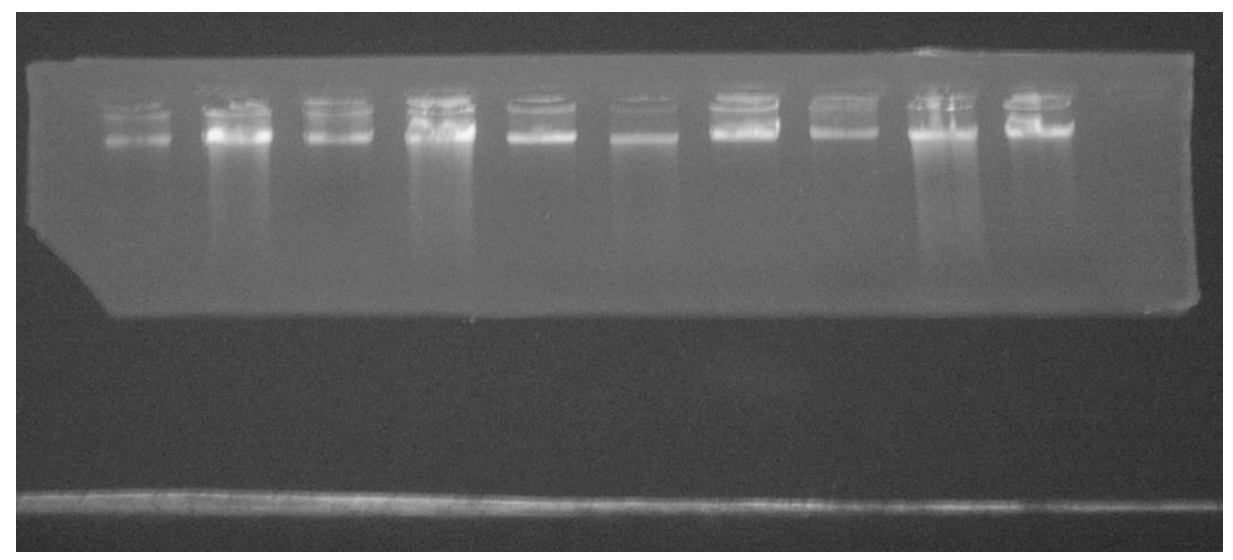

Figure 1. Visualization of local Papuan chicken DNA samples from electrophoresis on 1.5\% agarose gel media 
The amplification of target DNA fragments has been successfully carried out from the research chicken DNA samples using specific primers (Table 1) and under PCR conditions as in
Table 2. The electrophoresis results of the PCR products (amplification results) obtained are presented in Figure 2.

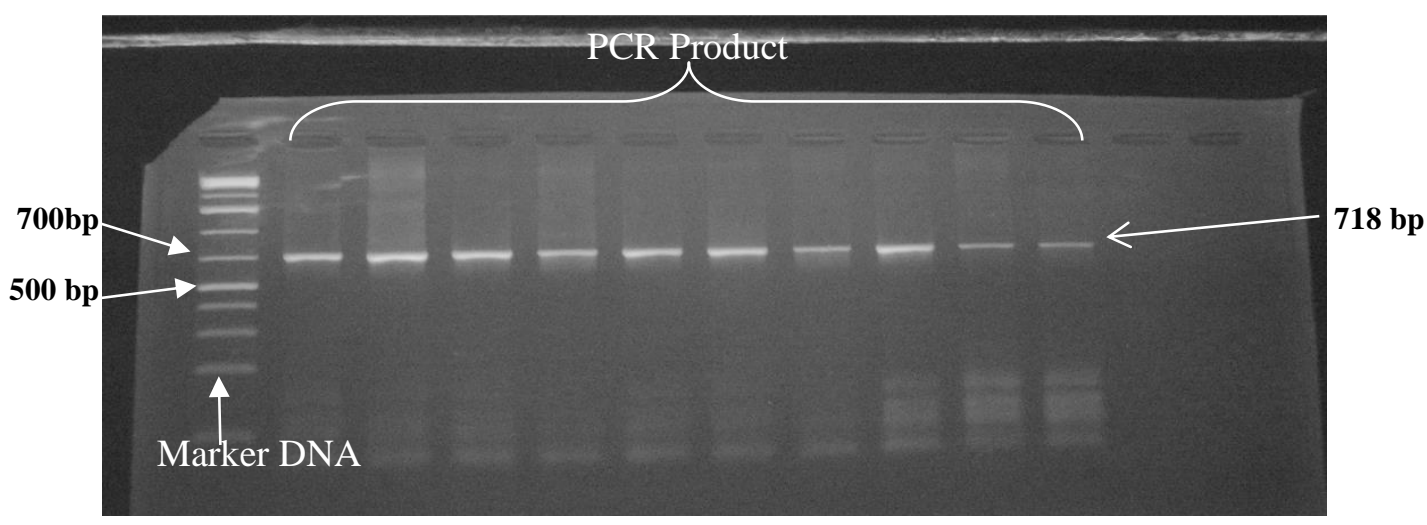

Figure 2. Visualization of the PCR product (718 bp) of the GHR gene (Intron-2) of research chickens on $1.5 \%$ agarose gel electrophoresis

\section{Genotype and Allele Frequency}

The digestion results of PCR products measuring 718 bp using the HindIII enzyme produced two kinds of banding patterns. Band I pattern consists of 2 bands, namely band 1 measuring $404 \mathrm{bp}$ and band 2 measuring $314 \mathrm{bp}$; while the band II pattern consists of 3 bands, namely band 1 measuring $314 \mathrm{bp}$, band 2 measuring $247 \mathrm{bp}$, and band 3 measuring $157 \mathrm{bp}$. Based on the guidelines for identifying genotypes at the GHR/intron-2 locus by Li et al. (2008) and Enayati and Rahimi-Mianji (2009), the pattern of band I ( 2 bands, namely $404 \mathrm{bp}$ and $314 \mathrm{bp}$ ) is called the A1A1 genotype, while the pattern of band II ( 3 bands, namely $314 \mathrm{bp}, 247 \mathrm{bp}$, and 157 bp) ) is called the A2A2 genotype. Feng et al. (1998) referred to the I-band pattern as the HindIII++ genotype, during the II-band pattern as the HindIII-- genotype. The genotypic symbol of the GHR/HindIII locus on intron 2 of the GHR gene in the discussion of this study refers to Feng et al. (1998).

The genotypes of the GHR/intron2/HindIII loci found in local Papuan chickens in this study were HindIII++ and HindIII--, while the HindIII+- genotype was not found (Figure 3 ). The HindIII-- genotype was found to be more (48 tails or $97.96 \%$ ) compared to the HindIII++ genotype, which was found only one tail or $2.04 \%$. Enayati and Rahimi-Mianji (2009), who examined 156 local Mazandaran chickens, also found the same genotype distribution, namely the HindIII++ genotype was found $(0.64 \%)$, the HindIII+genotype was not found, and the HindIII-genotype was found to be 155 tail $(99.36 \%)$. On the other hand, Roy et al. (2020) who conducted a study on White Leghorn (WLH) chickens from the IWH line, which is a line that has undergone family selection for the trait of annual egg production for 29 generations, reported that the chickens of this line had a much higher HindIII++ genotype frequency (96.6\%) compared to HindIII-- (3.3\%).

Based on this research, it is known that the GHR/intron-2/HindIII locus in local Papuan chickens has two kinds of alleles, namely HindIII+ and HindIII- alleles. In local Papuan chickens, the HindIII+ allele is a rare allele, with a frequency of only 0.02 . In contrast, the HindIIIallele was found with 0.98 (common allele) frequency. Based on these findings, the GHR/intron-2/HindIII locus in local Papuan chickens was categorized as a polymorphic locus because the common allele frequency was no more than 0.99 (Harris, 1994). The discovery of polymorphic properties at this locus opens the opportunity to study its relationship with quantitative traits, including growth characteristics, to find molecular markers of economic value quantitative traits in local Papuan chickens. 


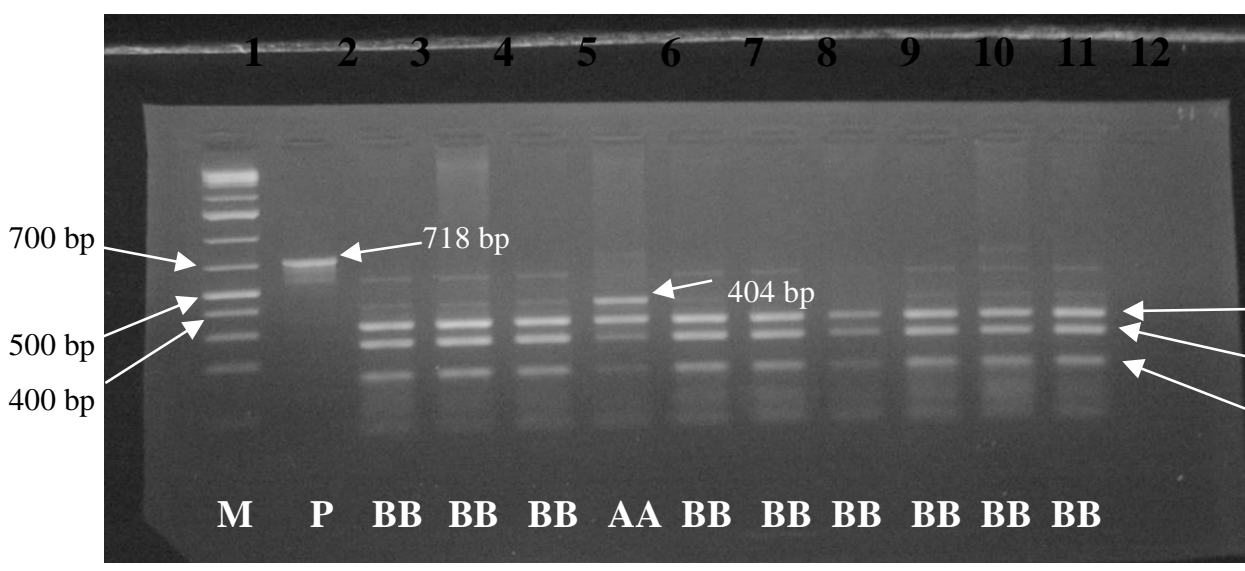

$314 \mathrm{bp}$

$247 \mathrm{bp}$

$157 \mathrm{bp}$

Figure 3. PCR-RFLP/HindIII results of the GHR gene (Intron-2) Papuan local chickens. Column 1: DNA markers (50 bp and 10,000 bp); column 2: PCR product (uncut, $718 \mathrm{bp}$ ); columns 3-5, and 7 12: genotype HindIII-- $(314,247,157 \mathrm{bp})$; column 6: HindIII++ genotype (404 bp and 314 bp).

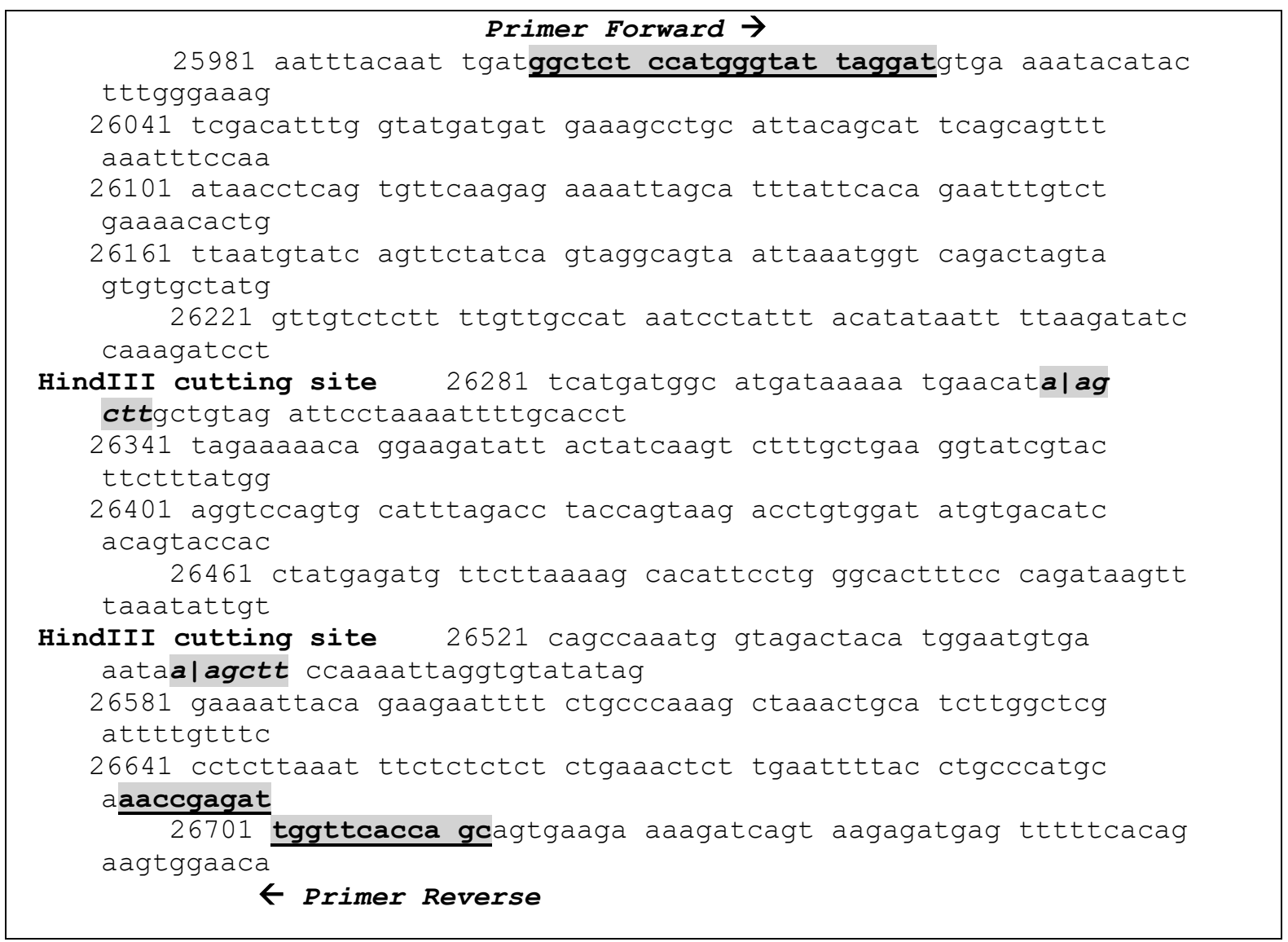

Figure 4. DNA fragment sequence (718 bp) in intron-2 of the GHR gene (GenBank: AC187590.3), forward and reverse primer positions (underline), and HindIII truncation site position (a|agctt).

It should be noted that the point mutation in intron-2 of the GHR gene is caused by $A / G$ transversion, and this point mutation can be detected by the HindIII enzyme (Li et al., 2008).
This point mutation produces two kinds of alleles, namely HindIII+ and HindIII- alleles. In this study, the HindIII+ allele was demonstrated by the success of the HindIII restriction enzyme in 
finding one truncation site (5'..A|AGCTT...3') along the DNA sequence of the PCR product so that the PCR product was cut into two DNA fragments (sizes 404 and $314 \mathrm{bp}$ ). While the HindIII- allele was shown by the success of HindIII finding two HindIII restriction enzyme cleavage sites (5 '..A|AGCTT...3') along the DNA sequence in the PCR product, therefore the PCR product was cut into three DNA fragments (size 314,247 , and 157 bp). Figure 4 shows the DNA sequence of the PCR product in this study (size 718 bp), while Figure 5 shows the HindIII truncation pattern (5'..A|AGCTT..3') along the
DNA sequence of the PCR product which produces 3 DNA fragments (HindIII+ allele). ) or 2 DNA fragments (HindIII- allele).

The number of studies conducted to examine the effect of the GHR/HindIII polymorphic locus on intron-2 of the chicken GHR gene on growth characteristics is still relatively small. Feng et al. (1997) reported that the genotype of the GHR/intron-2/HindIII locus was associated with body weight (age 140 days) in White Leghorn strain chickens, but was not associated with adult body weight (365 days).

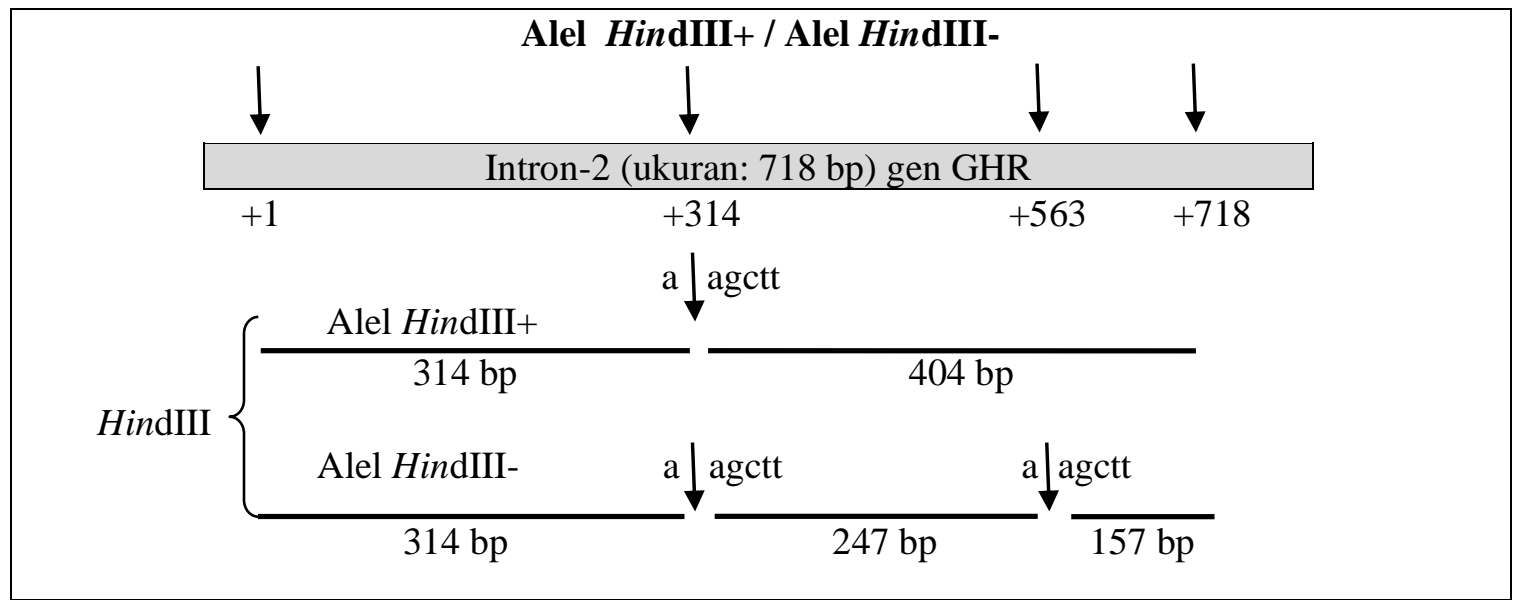

Figure 5. The pattern of HindIII cutting results in PCR products: 2 DNA fragments (allele A) and 3 DNA fragments (allele B)

Feng et al. (1998) reported that the selection of increasing body weight up to 9 generations in White Leghorn chickens had a significant effect on increasing the HindIII $(+)$ allele. In this study, the association of the GHR/HindIII polymorphic locus in intron-2 of the GHR gene with the growth characteristics of local Papuan chickens could not be carried out because the number of local Papuan chickens with HindIII++ (1 head) and HindIII-- (48 chickens) genotypes was not balanced.

\section{CONCLUSION}

The common allele from the GHR/intron2/HindIII locus in local Papuan chickens had a frequency of no more than $99 \%$, so this locus was categorized as a polymorphic locus. The discovery of polymorphic properties at this locus opens the opportunity to relate it to quantitative traits of economic value, including growth properties. However, the opportunity has not been carried out in this study because of an unbalanced number of research chickens on the genotypes found in this study. Similar research is needed involving a large number of samples to find molecular markers of quantitative traits of economic value in local Papuan chickens. In addition, it is also necessary to detect in other regions of the Papuan local chicken GHR gene, both in introns and exons.

\section{REFERENCES}

Artama, W. T. 1991. Rekayasa Genetika. Pusat Antar Universitas - Bioteknologi, Universitas Gadjah Mada, Yogyakarta.

Bingxue, Y., D. Xuemei, F. Jing, H. Xiaoxiang, W. Changxin, and L. Ning. 2003. Single nucleotide polymorphism analysis in chicken growth hormone gene and its associations with growth and carcass traits. Chinese Science Bulletin, 48(15): 1561 1564.

Burnside, J., S. S. Liou, and L.A. Cogburn. 1991. Molecular cloning of the chicken growth hormone receptor complementary deoxyribonucleic acid: Mutation of the 
gene in sex-linked dwarf chickens. Endocrinology 128 (6): 3183-3192.

Enayati, B., and G. Rahimi-Mianji. 2009. Genomic growth hormone, growth hormone receptor and transforming growth factor $\beta$-3 gene polymorphism in breeder hens of Mazandaran native fowls. African J. Biotechnology 8(14): 3154-3159.

Feng, X.P., U. Kuhlein, S.E. Aggrey, J.S. Gavora, and D. Zadworny. 1997. Trait association of genetic markers in the growth hormone and growth hormone receptor gene in White Leghorn strain. Poult. Sci. 76: 1770 -1775 .

Feng, X.P., U. Kuhnlein, R.W. Fairfull, S.E. Aggrey, J. Yao, and D. Zadworny. 1998. A genetic markers in growth hormone receptor gene associated with body weight in chickens. J. Hered. 89: 355 - 358.

Harris, H., 1994. Dasar-Dasar Genetika Biokemis Manusia. Edisi ketiga, diperbaharui Penerjemah: dr. Abdul Salam M. Sofro, Ph.D. Gadjah Mada University Press, Yogyakarta.

Haryani, E., 1999. Keragaman Morfologi dan Morfogenetik Ayam Kampung di Kabupaten Manokwari. Skripsi. Fakultas Pertanian, Universitas Cenderawasih, Manokwari.

Kirby, L.T. 1990. DNA Fingerprinting: An Introduction. M. Stockton Press. New York.

Lawrence, T.J.J., and V.R. Fowler. 2002. Growth of Farm Animals. 2nd ed. CABI Publishing, New York.

Li, H.F., W. Zhu, K. Chen, X. Wu, Q. Tang, and Y. Gao. 2008. Associations between GHR and IGF-1 gene polymorphism and reproductive traits in Wenchang chickens. Turk. J. Vet. Anim. Sci. 32 (4): 281-285.

Lumatauw, S. A. L. Killian, dan A. Supriyantono. 1995. Identifikasi Sifat-sifat Morfogenetik Ayam Buras di Irian Jaya. Laporan penelitian. Fakultas Pertanian, Universitas Cenderawasih, Manokwari.

Mu'in, M. A. 2000. Analisis potensi genetik beberapa ukuran tubuh ayam kampung. Jurnal Irian Jaya Agro, 7(2): 38- 42.

Muladno. 2002. Seputar Teknologi Rekayasa Genetika. Pustaka Wirausaha Muda dan USESE Foundation, Bogor.

Nei, M., and D. Kumar. 2000. Molecular Evolution and Phylogenetics. Oxford University Press, New York.

Nie, Q., B. Sun, D. Zhang, C. Luo, N.A. Ishag, M. Lei, G. Yang, and X. Zhang. 2005. High diversity of the chicken growth hormone gene and effect on growth and carcass traits. J. Hered. 96(6):698-703.

Rahayu, B.W.I. 1990. Pengkajian Beberapa Sifat Phenotip Ayam Kampung di Kota Manokwari. Skripsi. Fakultas Pertanian, Universitas Cenderawasih, Manokwari.

Roy, B.G., V.K. Saxena, U. Roy, and M. C. Kataria. 2020. PCR-RFLP study of candidate genes for egg production in layer chicken. Arch Anim Poult Sci, 1(3): 52-59.

Sambrook, J., Fritcsh, and T. Maniatis. 1989. Molecular Cloning Laboratory Manual. Second Edition, Vol. 3. Cold Spring Harbor Laboratory Press. USA.

Smith, R. G., and E. W. Brascamp. 1990. Genetic impact by advanced breeding technologies and gene transfer. In: Biotechnology for Control of Growth and Product Quality in Meat Production: Implications and Acceptability. Proceedings of an International Symposium, Washington, D.C. (5-7 Dec. 1990).

Steel, R. G. D., and J. H. Torrie. 1980. Principles and Procedures of Statistics. McGraw_Hill Publishing Co., New York.

Stephen, C.Y. Ip., X. Zhang, and C.L. Frederick, 2001. Genomic growth hormone gene polymorphism in native Chinese chickens. Experimental Biology and Medicine, 226(5), 458-462. 